Issue no. 26/2018

\title{
THE EFFECTIVENESS OF CRITICAL THINKING IN HIGHER EDUCATION
}

\author{
Eskja Vero \\ PhD Student,
} Department of Education, European University of Tirana, Albania eskja.vero@uet.edu.al

Assoc. prof. dr. Edi Puka

Department of Education, European University of Tirana, Albania

edi.puka@uet.edu.al

\section{DOI:10.24193/OJMNE.2018.26.13}

\begin{abstract}
This paper aims to explore the role of the university as an educational institution to encourage young people to express critical thinking. Critical thinking should become part of the teaching process so that students engage more in analyzing social problems that exist in society. Often, we see young people in audiences who discuss, interpret different social problems and do so based on personal judgment or personal experience and not on the basis of facts or arguments. At this point, there is a need for students to develop critical thinking skills as a necessity to understand and identify phenomena occurring in social reality. The focus of the paper is on the question: How much does the European University of Tirana enable the student to think critically? What are some of the basic skills you need to teach students to develop critical thinking and how much is critical thinking part of the curriculum? What are some skills that one needs to teach students for developing critical thinking and how much is the space of expressing critical thinking part of the curriculum? If critical thinking were to become more integrated in the teaching process, this would help students engage more in understanding knowledge, identifying social problems, and problem-solving abilities. The document focuses on the university as the main institution that should foster the power of critical thinking in students.
\end{abstract}

Keywords: critical thinking; curriculum; teaching method; education; students 
Issue no. 26/2018

\section{Introduction}

Facione argues that, teach people to make good decisions and you equip them to improve their own futures and become contributing members of society, rather than burdens to society. Becoming educated and practicing good judgment does not absolutely guarantee a life of happiness, virtue, or economic success, but it surely offers a better chance at those things. And it is clearly better than enduring the consequences of making bad decisions and better than burdening friends, family, and all the rest of us with the unwanted and avoidable consequences of those poor choices. (Facione, 2015, p. 2).

The study focuses on the effectiveness and the role of students with the development and expression of critical thinking as a necessary aspect to understanding our individual and social experiences. Critical thinking should become more part of the teaching process where students can engage in the identification, understanding and analysis of various social problems. But what are some of the basic skills that school should teach students to promote critical thinking? How much is part of curricula the space where students can express critical thinking? What are some of the methods used in teaching that stimulate critical thinking? This paper focuses on the university as the basic educational institution that should promote the preparation of students with the ability to express and apply critical thinking to every link of their student, professional, or academic performance in the future.

The paper will first address some of the key definitions provided for critical thinking, ranging from thinkers and classical philosophers, such as Bacon, Glaser, Paul, Scriven, Siegel etc. and other contemporary authors such as Crebert, Gardner \& Marzano, Facione, McKeachie etc. who through undergraduate studies have identified new ways of understanding and defining the critical thinking concept.

Second, we will argue some of the critical thinking skills that a student must learn to manifest them, not only in educational processes but also in everyday life practice. Some of the teaching strategies that promote critical thinking are case studies, focus groups, various discussions, problem-solving, reflections on a phenomenon in the form of essays, commentaries, reportages, etc. How does school promote these strategies or teaching methods to students? 
Issue no. 26/2018

Third, the paper tries to answer the question, why does the development of critical thinking in students play an important role in their personal and social life? In this issue, the focus is on the impact and efficiency of critical thinking in students and the role it plays in society. Among other things, some teaching strategies or practices will be presented on how the concept of critical thinking in everyday academic life can be developed with students.

\section{Classical definitions of 'Critical Thinking'}

Critical thinking has been defined in many different ways. Very broad definitions include "thinking which has a purpose or reflective judgement". Basically, the term "critical" is related to the Greek word "criterion", or standard to judge. The term "critical" is essentially related to thinking, judgment and appreciation as forms of thinking. The main object of critical thinking is related to determining the quality and value of your beliefs. Thinking critically has nothing to do with what you think, but how you think. "Critical thinking does not focus on the causes of your conviction, but on whether this conviction is worth it. A conviction is worth and should be kept if we have solid reasons to accept it. Critical thinking offers a whole set of compelling criteria in the techniques, attitudes, and principles that we use to evaluate beliefs and determine whether they are based on sustainable reasons.” (Vaughn \& MacDonald, 2010, p. 3). "Francis Bacon (1561 - 1626), founder of modern science, articulated the basic principles and methods of science and propagated their use in the prudent acquisition of accurate knowledge. He also warned of the risk of common mistakes in thinking, which could ruin all the efforts of science and lead to deformed perceptions and heavy mistakes”. (Vaughn \& MacDonald, 2010, p. 35). According to Bacon, 'scientific thinking' is based on 'facts or as we call it critical thinking' which is a very important tool in seeking truth. "He called the 'icons of the mind' the mistakes, because according to him, people not only make mistakes, but also fetish them, just as we do fetish false gods" (Ibid.).

Eduard Glaser in 1941 argued that critical thinking is a human ability to create "a strong persistence in search of data that support any beliefs or assumptions we have." (Fisher, 2001, p. 3). Richard Paul in 1993 gives an interpretation other than Glaser's. According to him, critical thinking is the way of thinking about "any subject, context, problem, in which 
Issue no. 26/2018

the critical thinker in such cases proves his or her qualities of thinking and masterfully builds the natural structures of thinking and sets intellectual standards on them". (Fisher, 2001, p. 4).

Michael Scriven argued that "critical thinking is an academic competency akin to reading and writing. It defines it thus: critical thinking is skilled and active interpretation and evaluation of observations and communications, information and argumentation. He defines critical thinking as a 'skilled' activity for reasons similar to those mentioned above. To be critical, thinking has to meet certain standards - of clarity, relevance, reasonableness” (Ibid.)

Siegel has defined critical thinking as an "education in knowledge of rationality," McPeck in 1981 described the term "skepticism or reflective doubt," Barnett in 1997 with the term "Critical Self Reflection", while Toulmin, Rieke and Janick in 1984 linked critical thinking to reasoning to use it later as "central activity in introducing reasons in support of a particular issue or argument". (Vyncke, 2012, pp. 9-10). According to Ennies in 1985, critical thinking is an "reflective and reasonable thinking that is focused on deciding what to believe or do”. (Lai, 2011, p. 6).

\section{Contemporary definitions of 'Critical Thinking'}

Gardner and Marzano are two research scientists who, in the study they have made, have observed the role played by the creation of an interactive lesson for successful student learning. According to them, "studies show that learning in an active, organized and well thought out learning is often far more complete and fruitful. Learning fruitfully means that you can think of what you learn. To apply it to life situations, to use it as a basis for further learning and continuing to learn independently " (Temple, Crawford, Saul, Mathews \& Makinster, 2006, p. 1).

Other authors have seen critical thinking as a cognitive ability regarding rational judgment (Vyncke, 2012). Critical thinking is reasoning, reflection, responsiveness, and thinking ability that is focused on what to believe or do. "We understand critical thinking to be purposeful, self-regulatory judgment which results in interpretation, analysis, evaluation, and inference, as well as explanation of the evidential, conceptual, methodological, criteriological, or contextual considerations upon which that judgment is based”. (Facione, 2015). "The ideal critical thinker is habitually inquisitive, well-informed, trustful of reason, 
Issue no. 26/2018

open-minded, flexible, fair-minded in evaluation, honest in facing personal biases, prudent in making judgments, willing to reconsider, clear about issues, orderly in complex matters, diligent in seeking relevant information, reasonable in the selection of criteria, focused in inquiry, and persistent in seeking results which are as precise as the subject and the circumstances of inquiry permit”. (Ibid).

Tara DeLecce, a psychologist who in one of the online lectures held on critical thinking, argued that "additionally, critical thinking can be divided into the following three core skills: Curiosity is the desire to learn more information and seek evidence as well as being open to new ideas. Skepticism involves having a healthy questioning attitude about new information that you are exposed to and not blindly believing everything everyone tells you. Finally, humility is the ability to admit that your opinions and ideas are wrong when faced with new convincing evidence that states otherwise”. (DeLecce, 2015).

Thinking is defined in different ways, some authors define it "as a psychic process, as a form of general reflection of reality on human consciousness through notions, judgments and reasoning". Authors call this "conscious thinking" because it is affected by pedagogical work of educators. (Jashari \& Ballhysa, 2005, p. 23).

Kec and Ara (2005), provide another kind of definition of critical thinking as follows:

"Critical thinking is a process that brings a result. It is part of the thinking process, by which every person critically thinks, as a natural path of interaction with ideas and information; it is an active process that develops with a certain purpose or happens by chance, which permanently makes students control the information and meet the challenges; include; adapt or disseminate information. Critical thinking occurs when students begin to reflect on what they read, start asking questions, start linking knowledge that they know and learn new knowledge, select information, analyze behavior, actions and situations, argue and maintain attitudes assigned to them.” (Gjokutaj, Shahini, Markja, Zisi \& Muça, p. 38).

The concept of critical thinking in the age of modernity and in the history of philosophical thought of the $15^{\text {th }}$ to the $16^{\text {th }}$ centuries is mostly related to the concept of reflecting critically. Critical reflection helps to stay active, in our individual and social experiences. Critical reflection enables us to reconsider our previous judgments and assessments, and to complement them on the basis of what new facts suggest. "Critical 
Issue no. 26/2018

reflection makes each of us, at school or after its end, consistently, to remain an active student. By critically reflecting upon institutional organization, economic and cultural conditions, and on the problems of society, we reconsider our previous trials and assessments, adapt them, complement them, and enrich them on the basis of what the new facts we discover through our careful observations and through critical reflection on them" (Tarifa, 2014, p. 202).

Philosophy science was born from reflexion on the essence. Descartes (1981) is known for the formula "I doubt, I think, so I am". Hence, he integrated into the history of philosophy the notion of "methodical suspicion". According to him, suspicion allows him to find the required security. Descartes required the analysis of all elements of thought to the simplest ones. Sort these simple elements in an increasingly complex order, so that complex terms can be clearly understood. (Hersh, 1981, p. 95).

The features of a 'critical thinker' according to Crebert (2011) are listed as follows:

- Inquisitiveness about a wide range of issues;

- Desire to become and remain well-informed;

- Alertness to opportunities to use critical thinking;

- Trust in the processes of reasoned inquiry;

- Self-confidence in own abilities to reason;

- Open-mindedness towards divergent world views;

- Flexibility in considering alternatives and opinions;

- Understanding of the opinions of other people;

- Fair-mindedness in appraising reasoning;

- Honesty in facing own biases, prejudices, stereotypes etc.;

- Discretion in suspending, making or altering judgments; and

- Willingness to reconsider and revise views where necessary. (Crebert et al., 2011, p. 6). 
Issue no. 26/2018

\section{The basic skills of a critical thinker}

Almost everyone who has worked in the critical thinking tradition has produced a list of thinking skills which they see as basic to critical thinking. For example, Edward Glaser (1941) listed the abilities:

- $\quad$ To recognize problems;

- To find workable means for meeting those problems;

- To gather and marshal pertinent information;

- To recognize unstated assumptions and values;

- To comprehend and use language with accuracy, clarity, and discrimination;

- $\quad$ To interpret data;

- To appraise evidence and evaluate statements;

- To recognise the existence of logical relationship between propositions;

- To draw warranted conclusions and generalisations. (Fisher, 2001, p. 6)

According to Willison \& O’Reagan (2006), they argued these abilities:

- $\quad$ determine the need for knowledge;

- find and generate the information;

- critically evaluate the information;

- organise the information;

- $\quad$ synthesise, analyse and apply the new knowledge; and

- communicate the knowledge. (Crebert et al., 2011, p. 13)

\section{Teaching methods that promote the development of critical thinking}

There are several methods that encourage critical thinking among students. One of the first activities known as the three phases or PNP model (Prediction, Knowledge Building, and Reinforcement) was created by authors Joseph Vaughn and Thomas Estes in 1986, and then the curriculum became more popular in pedagogical practices nowadays, like the ERR 
Issue no. 26/2018

structure (Evocation, Realization of Meaning and Reflection). (Temple, Crawford, Saul, Mathews \& Makinster, 2006, p. 2).

According to Crebert (2011), using concept maps in planning a curriculum or instruction on a specific topic helps to make the instruction conceptually transparent to students. Many students have difficulty identifying and constructing powerful concepts and propositional frameworks, leading them to see science learning as a blur of myriad facts or equations to be memorized. If concept maps are used in planning instruction and students are required to construct concept maps as they are learning, previously unsuccessful students can become successful in making sense out of science and acquiring a feeling of control over the subject matter. The benefits of concept maps are that they enable students to:

- Establish connections between ideas they already have;

- Connect new ideas to existing knowledge; and

- Organise ideas in a logical, but not rigid, structure that can be updated. (Crebert et al., 2011, pp. 10-11).

\section{Using debating to analyse and evaluate issues}

\begin{tabular}{|c|c|}
\hline \multicolumn{2}{|c|}{ Skills developed through debating } \\
\hline $\begin{array}{c}\text { Oral } \\
\text { communication }\end{array}$ & $\begin{array}{l}\text { Persuasive verbal arguments. Confidence and clarity } \\
\text { in thinking. Language skills. }\end{array}$ \\
\hline $\begin{array}{l}\text { Structuring an } \\
\text { argument }\end{array}$ & $\begin{array}{l}\text { Big picture perspective. Ability to define topic, terms } \\
\text { and premise. Stating what is to be proved, providing } \\
\text { supporting evidence and examples. Countering opposing } \\
\text { arguments. }\end{array}$ \\
\hline $\begin{array}{l}\text { Logical and } \\
\text { analytical thinking }\end{array}$ & Clear lines of argument. \\
\hline Teamwork & $\begin{array}{l}\text { Collaboration on common task. Understanding of role } \\
\text { in order of debate. }\end{array}$ \\
\hline Time management & Succinct arguments presented in restricted time. \\
\hline
\end{tabular}


Issue no. 26/2018

\begin{tabular}{|c|c|}
\hline skills & Effective use of time to prepare and deliver arguments. \\
\hline Research skills & $\begin{array}{l}\text { Ability to find and utilise relevant and current } \\
\text { literature/findings on the topic. Ability to identify key points } \\
\text { and summarise. }\end{array}$ \\
\hline $\begin{array}{l}\text { Reading the } \\
\text { audience }\end{array}$ & $\begin{array}{l}\text { Knowing what the audience already knows/expects to } \\
\text { hear on the topic. Tailoring the content, pace and tone of a } \\
\text { presentation to the audience. Presenting information in an } \\
\text { engaging and entertaining style. }\end{array}$ \\
\hline
\end{tabular}

\section{Reading}

Three important purposes of reading critically are:

- to provide evidence to back up or challenge a point of view;

- to evaluate the validity and importance of a text/ position;

- to develop reflective thought and a tolerance for ambiguity.

\section{Strategies for reading critically}

\begin{tabular}{|c|l|}
\hline \multicolumn{1}{|c|}{ Ask questions about: } & For example \\
\hline Your purpose & Why? \\
\hline The context of the text & Why written? \\
& Where? \\
When? & Who? \\
& How relevant? \\
\hline text $\quad$ Is there a clear argument? Do the parts fit together \\
\hline The arguments & logically? \\
\hline The evidence used & Are they fair? Do they leave out perspectives of \\
\hline
\end{tabular}


Issue no. 26/2018

\begin{tabular}{|c|c|}
\hline & $\begin{array}{l}\text { an authority in this field? Is the evidence evaluated from } \\
\text { different perspectives? }\end{array}$ \\
\hline The language used & $\begin{array}{r}\text { Is the language coloured to present some things as } \\
\text { more positive than others? Are claims attributed clearly? }\end{array}$ \\
\hline
\end{tabular}

If we want to generalize it, critical thinking has three parts:

1. First, critical thinking involves asking questions.

2. Second, critical thinking involves trying to answer those questions by reasoning them out.

3. Third, critical thinking involves believing the results of our reasoning. ('What is critical thinking', 2017, pp. 5-6).

Thinking critically about solving a problem, on the other hand, begins with asking questions about the problem and about ways to address it:

1. What is the purpose behind the problem?

2. What is a good way to begin?

3. Do I have all the information I need to start solving the problem?

4. What are some alternative ways of solving the problem assigned?

5. Can the problem be solved? Does it even make sense? ('What is critical thinking', 2017, pp. 5-6).

\section{Impact of expressing critical thinking in society}

According to authors Lau and Chan, qualitative knowledge is the student's ability to express critical and creative thinking, intellectual flexibility, competence to analyse information and integrate various sources of knowledge in problem solving. According to them, critical thinking is the basis of "science" and "democracy". Science requires the use of "critical reasoning" in different experiments and theoretical confirmations. The function of liberal democracies requires citizens who think critically about social issues to inform their judgments about proper governance and overcome the various prejudices and disagreements that occur. (Lau \& Chain, 2016). 
Issue no. 26/2018

Critical thinking should be more focused on university curricula. Yanklowitz (2013) said that the goal of an argument curriculum is to enhance the development of the responsible citizens and the pedagogical methodology consists of cultivating argument skills, epistemic development, and moral development. Also, Calfee and Chambliss (1987) argue that "students are unlikely to develop critical thinking skills naturally when their class reading assignments consist only of narrative and explanatory texts, as opposed to argumentative texts”. If the transmission of the knowledge of a lecture, text, or information of any kind were to take place according to the dialogue-questioning process, the students would be more involved in the learning process and begin to develop their own arguments on the themes discussed by the subject lecturer. (Yanklowitz, 2013).

So, a major part of learning how to think critically is learning to ask the questions- to pose the problems-yourself. That means noticing that there are questions that need to be addressed; admitting that there are problems. Often, this is the hardest part of critical thinking. This is true not just in school, but in daily life as well. People often do not ask themselves, "How can I best get along with my parents (my partner, my co-workers, my friends) in this situation?” Instead, they continue relating to them in habitual and unexamined ways. If your goal is to improve some aspect of your daily life, begin by asking yourself some questions: What are some concrete things I can do to get better grades? To meet new people? To read more effectively? To make the subject matter of this course meaningful in my life? To be effective, you need to really ask these questions. It is not enough just to say the words. ('What is critical thinking', 2017, pp. 5-6).

\section{Data and Methods}

The purpose of this study is to explore the role of the European University of Tirana, as an educational institution, in promoting the ability of young people to express critical thinking. Critical thinking should become part of the teaching process so that students engage more in analysing social problems that exist in society. Often, we see young people in audiences who discuss, interpret different social problems and do so, based on personal judgment or personal experience and not based on facts or arguments relying on them. At this 
Issue no. 26/2018

point, the need arises for students to develop this ability to think critically as a need to understand and identify phenomena occurring in social reality.

The objectives of this study are to:

- Identify critical definitions of the critical thinking concept.

- $\quad$ Analyse some of the basic skills of being a critical thinker.

- $\quad$ Introduce key methods that promote critical thinking in education.

- $\quad$ Analyse the importance of student learning with critical thinking in relation to life and society.

The research questions include the purpose and objectives of the study:

Research question 1: How much does the European University of Tirana enable the student to think critically?

Research question 2: What are the skills and methods that pedagogues use in the classroom to encourage critical thinking in students?

\section{This work will support two hypotheses:}

Hypothesis 1: The concept of thinking critically is not sufficiently cultivated at UET students.

Hypothesis 2: If critical thinking were to become more integrated in the teaching process, this would help students engage more in understanding knowledge, identifying social problems, and problem-solving skills.

In this study, a random sample was used. Sampling is $(\mathrm{n}=200)$ students. Questionnaires were distributed to Bachelor students at the European University of Tirana. The process was conducted during the development of a joint teaching class which included students from various branches in social sciences such as Psychology, Sociology, Public Relations - Communication, Political Science and International Relations.

Two self-reporting questionnaires were designed to measure the level of critical thinking development. The questionnaire contains a total of 27 questions. Questions are encoded from 1 (never) to 5 (usually or very often). This questionnaire was accessed by a private organization such as the Foundation for Critical Thinking, which studies critical thinking. (Critical Thinking Interview Profile for Teachers and Faculty and Critical Thinking Interview Profile for College Students.) 
Issue no. 26/2018

\section{Results}

Following are the relevant findings, in an effort to answer research questions and to validate the hypotheses of the study: by gender $61.5 \%$ were females, $9 \%$ were male, and 29.5\% abstained. The most involved age group was 19 - 21 years old with 63\%, 22-25 years with 11\%, 26-28 years with 3\%, 35 years and over with $2 \%$, and abstention resulted in $20.5 \%$ of responses. The student study program was listed as follows. 35.4\% study for Psychology, 5\% for Sociology, $8.5 \%$ Political Science, $12.5 \%$ in International Relations, $7.5 \%$ Public Relations - Communication, and about 32\% abstained.

The level related to the explanation of the critical thinking concept to students by their pedagogues results from findings where $31 \%$ of students express themselves at the level several times but not often, $23 \%$ are neutral, $22.5 \%$ say that this concept is rarely explained, $12.5 \%$ are expressed usually or very often, and $11 \%$ say that this concept has never been explained to them.

In $29 \%$ of students the definition of the critical thinking concept has been developed several times, but not often along the course or course programme, $26.5 \%$ stated that definitions of critical thinking concept were rarely developed, 21\% expressed neutrally, $12.5 \%$ never, and $11 \%$ with usually or very often.

Literature study on the use of critical thinking results in $29.5 \%$ rarely expressed, $27.5 \%$ expressed several times but not often, $22.5 \%$ expressed neutrally, $11 \%$ usually or very often, and $19 \%$ never.

The level of student encouragement for critical thinking by the lecturers results in $29.5 \%$ at several times, but not often, $24.5 \%$ more commonly or very often, $20 \%$ neutral, $17 \%$ less, and $9 \%$ never.

The level of use of teaching methods that promote critical thinking such as method of questioning, method of discussion and classroom debates, group collaboration method, oral presentation method in Power Point, method of problem solving, on the whole, appears to occur in $43.5 \%$ of cases with usually or very often, $23.5 \%$ with several times but not often, $14 \%$ with neutral, $13.5 \%$ rarely, and $5.5 \%$ with never.

The methods that most often use pedagogues in teaching, 38\% express abstention regarding the use of a particular method of the sorted ones, $25.5 \%$ say that the method of 
Issue no. 26/2018

discussion and debate in the classroom is developed, $24.5 \%$ mention the method of oral presentations in Power Point, 5\% the collaboration method in the group, $8 \%$ the method of questioning repeatedly, and 3\% the problem-solving method.

The level of student learning by the professors to understand the text content occurs in $32 \%$ sometimes but not often, $24 \%$ neutral, $21 \%$ usually or very often, $18 \%$ rarely, and $5 \%$ never.

The level of information storage without understanding the true content, in view of receiving only a student's final assessment, results in 29.5\% never occurring, 22\% say it happens rarely, $19.5 \%$ think this happens several times but not often, $16.5 \%$ are neutral, and $14 \%$ say usually or very often.

Encouraging critical thinking in the learning process according to the findings are $29.5 \%$ with several times, but not often, 25.5\% rarely, 23\% expressed neutral, and 19.5\% expressed usually or very often.

The level of student clarification by the professors to be precise, for questioning, problematic or a particular subject during teaching is $32 \%$ with usually or very often, $26.5 \%$ with several times but not often, $19 \%$ rarely, $18 \%$ neutral, and $4.5 \%$ with never.

The level of understanding in the organized way of the key concepts of the topic results in $30 \%$ at several times but not often, $26 \%$ usually or very often, $20.5 \%$ rarely, $19 \%$ neutral, and $4.5 \%$ never.

The level of the student's ability to draw conclusions based on data or information collected, according to findings, is $34.5 \%$ rarely, $25 \%$ neutral, $18.5 \%$ usually or very often, $18 \%$ few times but not often, and $4 \%$ never.

The level of student training to make the differences in the assumptions, conclusions and consequences of a particular phenomenon, is $27 \%$ several times, but not often, $26 \%$ neutral, $21.5 \%$ usually or very often, $20 \%$ rarely, and $10.5 \%$ never.

The level of students' ability to think logically according to the findings is $31 \%$ several times, but not often, $26.5 \%$ usually or very often, $20.5 \%$ neutral, $18.5 \%$ rarely, and $3.5 \%$ never. 
Issue no. 26/2018

The level of student training to maintain a personal attitude against the arguments that arise, results in 36\% several times, but not often, $27 \%$ neutral, $16.5 \%$ rarely, $15.5 \%$ usually or very often, and $5 \%$ never.

\section{Conclusions}

This study was designed to investigate the perceptions of students about how the university as an educational institution encourages them to express critical thinking. But in this study we understand that critical thinking has difficulties in implementation in teaching and learning in students.

\section{The difficulties in the implementation of critical thinking while teaching UET} students are:

1. The level related to the explanation of critical thinking concept to students by their professors results in the majority of $62 \%$ thinking that this process occurs several times but not often, $25 \%$ of students argue that this concept is rarely explained, $13 \%$ are neutral about the explanation of the concept. This indicates that the concept of critical thinking should be given in some definitions where students need to be taught how to use it.

2. About giving definitions of critical thinking in teaching during course development, $58 \%$ of students said that definition of critical thinking was explained sometimes but not often, which can greatly affect the non-recognition of this concept. Only $22 \%$ said that this concept was developed usually or very often during teaching.

3. Increasing the level of understanding in organized way is the key due the concepts of structured creative abilities such as: student's ability to draw conclusions based on data or information collected; student's ability to make the differences in the conclusions and consequences of a particular phenomenon; students' ability to think logically; student's ability to maintain a personal attitude against the arguments that arise;

4. Encouraging critical thinking in the learning process according to the findings occurs 59\% several times, but not often. And $40 \%$ are neutral. The data shows that encouragement is an indicator of the positive path of strengthening critical thinking in students, but more work is needed to keep the level of neutrality even smaller. 
Issue no. 26/2018

Lai has argued:

"Educators have long seen critical thinking as a desirable educational outcome. More recently, the Partnership for 21st Century Skills has identified critical thinking as one of several skills necessary to prepare students for post-secondary education and the workforce. Typically, critical thinking is believed to include the component skills of analysing arguments, making inferences by using inductive or deductive reasoning, judging or evaluating, and making decisions or solving problems. Critical thinking entails cognitive skills, or abilities, and dispositions. These dispositions, which can be seen as attitudes, or habits of mind, include open- and fair-mindedness, inquisitiveness, flexibility, a propensity to seek reason, a desire to be well-informed, and a respect for and willingness to entertain diverse viewpoints.” (Lai, 2011, p. 42).

Why the Need for Critical Thinking?

According to Blunkett, we have entered in a new century, in which the structure and the way of learning will determine our lives as never before ... if we have success or salvation, either as individuals or as a state, this will depend on our knowledge, skills and understanding. The concept of 'getting used to learning continually' to prepare to live in a world with persistent and fast-paced changes is ruling on modern education policies. Accumulation of knowledge and competences of the purely technical nature of the type 'professional education' are now considered with less priority than critical intelligence, openness to change and quick adaptation to new ones, social competences, the logic of sustainable development. (Civici, 2013, p. 292).

\section{Bibliography}

- $\quad$ CIVICI, A. (2013). State or Market / Which development model we choose. Tirana: UetPress Publications.

- $\quad$ CREBERT, G., PATRICK, C.-J., CRAGNOLINI, V., SMITH, C., WORSFOLD, K., \& WEBB, F. (2011). Critical Evaluation Skills Toolkit (2nd ed). Retrieved May 20, 2016 from http://www.griffith.edu.au.

- DELECCE, T. (2015). What is Critical Thinking? - Definition, Skills \& Meaning[Lecture]. Retrieved April 30, 2016 from http://education-portal.com. 
Issue no. 26/2018

- FACIONE, P. (2015). Critical Thinking: What It Is and What It Couns. Insight assessment. Retrieved January 30, 2016 from www.insightassessment.com.

- $\quad$ FISHER, A. (2001). Critical Thinking. An Introduction. United Kingdom: Cambridge University Press.

- $\quad$ GJOKUTAJ, M., SHAHINI, L., ZISI, A., \& MUÇA, E. (2005). Student-Centered Teaching. Tirana: Training and Qualification Center for Education (QTKA).

- $\quad$ HERSH, Zh. (1981). Philosophical Habit. Tirana: Dituria publications.

- $\quad$ JASHARI, A. \& BALLHYSA, A. (2005). Manual for critical thinking during reading and writing. Elbasan: Sejko.

- LAI, R. E. (2011). Critical Thinking: A Literature Review.(Research Report). Retrieved June 20, 2016 from http://www.pearsonassessments.com/.

- Learning Centre. (2016). Developing Critical Thinking Skills. Retrieved May 15, 2016 from http://www.usyd.edu.au/lc..

- $\quad$ Personhighered (2017). Chapter 1, What is Critical Thinking. Retrieved 15 April, 2016 from https://www.pearsonhighered.com/assets/samplechapter

- $\quad$ TARIFA, F. (2014). Sociological Imagination and our Social World. Tirana: Onufri.

- $\quad$ TEMPLE, Ch., CRAWFORD, A., SAUL, W., MATHEWS, R. S. \& MAKINSTER, J. (2006). Teaching and Learning Strategies for Thinking Classes. Tirana: Center for Democratic Education (CDE).

- VAUGHN, L. \& MACDONALD, Ch. (2010). The Power of Critical Thinking. Tirana: Center for Democratic Education (CDE).

- VYNCKE, M. (2012). The concept and practice of critical thinking in academic writing: an investigation of international students perceptions and writing experiences. (Doctoral dissertation). Retrieved May 31, 2016 from www.englishagenda.britishcouncil.

- $\quad$ YANKLOWITZ, Sh. R. (2013, 15 December). A Society with Poor Critical Thinking Skills: The Case for 'Argument' in Education. (Web blog article). Retrieved June 3, 2016from www.m.huffpost.co. 